\title{
触 New Disease Reports \\ First report of a tospovirus in a commercial crop of Cape gooseberry in Brazil
}

\author{
M. Eiras ${ }^{1}$, I.F.D. Costa $^{2}$, A.L.R. Chaves ${ }^{1}$, A. Colariccio ${ }^{1}$, R. Harakava ${ }^{1}$, F.A.O. Tanaka ${ }^{3}$, R.M. Garcêz ${ }^{1}$ and L.A. Silva $^{1}$ \\ ${ }^{1}$ Laboratory of Plant Virology, Instituto Biológico, 04014-002, São Paulo, SP, Brazil; ${ }^{2}$ University Federal of Santa Maria, RS, \\ Brazil; ${ }^{3}$ University of São Paulo, Piracicaba, SP, Brazil
}

*E-mail: eiras@biologico.sp.gov.br

Received: 08 Feb 2012. Published: 21 May 2012. Keywords: Tomato chlorotic spot virus, TCSV, Physalis peruviana

Viruses from the genus Tospovirus (family Bunyaviridae) are widespread in the Americas, where the following species have been reported: Tomato chlorotic spot virus (TCSV), Tomato spotted wilt virus (TSWV), Groundnut ringspot virus (GRSV), Chrysanthemum stem necrosis virus (CSNV), Zucchini lethal chlorosis virus (ZLCV), Impatiens necrotic spot virus (INSV), Iris yellow spot virus (IYSV) (Jones, 2005),

Alstroemeria necrotic streak virus (ANSV), Melon severe mosaic virus (MeSMV) and Bean necrotic mosaic virus (BeNMV) (Ciuffo et al., 2009; Hassani-Mehraban et al., 2010; Oliveira et al., 2011).

This work describes the identification of a virus isolated from a commercial crop of Cape gooseberry (Physalis peruviana) in October 2009 in Santa Maria, State of Rio Grande do Sul, Brazil. The disease was identified in a 5 ha cultivated area, where $100 \%$ of the plants were showing symptoms of stunting, mosaic, necrosis and foliar distortion (Fig. 1). Spherical particles measuring $80-100 \mathrm{~nm}$ in diameter were observed by electron microscopy, giving the initial evidence that a tospovirus might be involved in the disease. Sap from the infected leaves of five different Cape gooseberry plants were inoculated on healthy indicator plants: Petunia hybrida and Chenopodium amaranticolor reacted with local lesions; Datura stramonium, Solanum gilo, S. lycopersicum, S. nigrum, Physalis angulata, $P$. floridana and $P$. peruviana (Fig. 1) displayed systemic symptoms. Host reactions were typical for those caused by tospoviruses and symptoms on Physalis species reproduced those observed in the original samples. Testing by plate trapped-ELISA, a positive reaction was only obtained from all five samples using anti-TCSV antiserum (Embrapa, CNPH, Brazil). Negative ELISA results were obtained using antiserum against four other tospoviruses: Tomato spotted wilt virus, Groundnut ringspot virus, Impatiens necrotic spot virus and Chrysanthemum stem necrosis virus. RT-PCR was performed using primers designed to conserved regions of the tospoviral S RNA (Eiras et al., 2001). This generated 440 bp DNA fragments, whose sequence revealed a high degree of nucleotide identity with TCSV isolates from Argentina (98-99\%) and Brazil (93-95\%). Alignment of the partial coat protein nucleotide sequences showed that the Physalis TCSV isolate (GenBank Accession No. JQ034525) clustered with other TCSV isolates, sharing a clade with Argentinean isolates (Fig. 2).

Cape gooseberry is a fruit crop of great nutritional and economic value, which has gradually gained acceptance in international markets, due to its flavour and medicinal properties. In Brazil, it was introduced as a

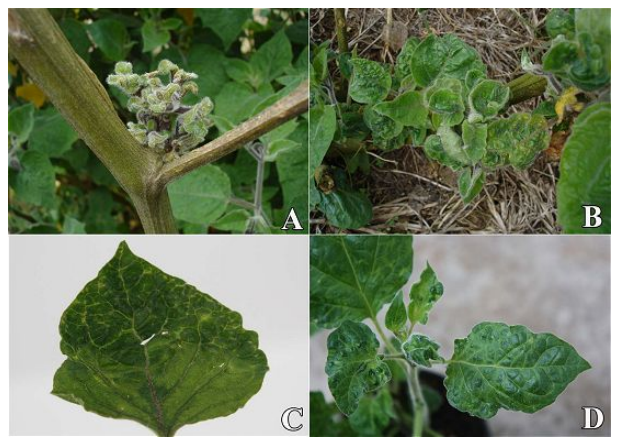

Figure 1

To cite this report: Eiras M, Costa IFD, Chaves ALR, Colariccio A, Harakava R, Tanaka FAO, Garcêz RM, Silva LA, 2012. First report of a tospovirus in a commercial crop of Cape gooseberry in Brazil. New Disease Reports 25, 25. [doi:10.5197/j.2044-0588.2012.025.025] (C) 2012 The Authors commercial crop into small farms in southern Brazil (Rufato et al., 2008). To our knowledge, this is the first report of natural occurrence of TCSV in commercial crops of Cape gooseberry. To date the disease is restricted to Rio Grande do Sul State. Further epidemiological studies are necessary for understanding the spread of TCSV into this relatively new introduced crop in Brazil.

\section{References}

Ciuffo M, Kurowski C, Vivoda E, Copes B, Masenga V, Falk BW, Turina M, 2009. A new Tospovirus sp. in cucurbit crops in Mexico. Plant Disease 93, 467-474. [doi:10.1094/PDIS-93-5-0467]

Eiras M, Resende RO, Missiaggia AA, Ávila AC, 2001. RT-PCR and dot blot hybridization methods for a universal detection of tospoviruses. Fitopatologia Brasileira 26, 170-175.

[doi:10.1590/s0100-41582001000200009]

Hassani-Mehraban A, Botermans M, Verhoeven JTJ, Meekes E, Saaijer J, Peters D, Goldbach R, Kormelink R, 2010. A distinct tospovirus causing necrotic streak on Alstroemeria sp. in Colombia. Archives of Virology $\mathbf{1 5 5}$, 423-428. [doi:10.1007/s00705-010-0590-7]

Jones DR, 2005. Plant viruses transmitted by thrips. European Journal of Plant Pathology 113, 119-157. [doi:10.1007/s10658-005-2334-1]

Oliveira AS, Bertran AGM, Inoue-Nagata AK, Nagata T, Kitajima EW, Resende RO, 2011. An RNA-dependent RNA polymerase gene of a distinct Brazilian tospovirus. Virus Genes 43, 385-389.

[doi:10.1007/s11262-011-0639-z]

Rufato L, Rufato AR, Schlemper C, Lima CSM, Kretzschmar AA, eds, 2008. Aspectos técnicos da cultura da Physalis. Lages, Brazil: CAV/UDESC; Pelotas, Brazil: Universidade Federal de Pelotas. 